\title{
Magyar kutatók külföldön: a női és férfi karrierutak főbb jellemzői ${ }^{1}$
}

\author{
FÉNYES HAJNALKA ${ }^{2}$ - PAKSI VERONIKA ${ }^{3}$ - TARDOS KATALIN ${ }^{4}-$ \\ MARKOS VALÉRIA ${ }^{5}$-SZIGETI FRUZSINA ${ }^{6}$
}

\begin{abstract}
ABSZTRAKT
A nemzetközi mobilitás napjainkra nemcsak a sikeres kutatói életút részévé vált, de egyre erôsebb szakmai elvárásként fogalmazódik meg. Az elmúlt évtizedekben ugrásszerü növekedésnek indult migrációt a nemzetközi szakirodalom már mélyebben vizsgálja, de a magyar kutatók külföldi karrierjéröl keveset tudunk. Ráadásul, ahogyan a kutatói karrierek, úgy a nemzetközi mobilitás is erősen meghatározott a nemek alapján, és számos módon összekapcsolódhat az egyenlőtlenségek különböző típusaival. Tanulmányunk célja feltárni a külföldre távozott magyar kutatók föbb jellemzôit, különös tekintettel a nemek közötti azonosságokra és különbségekre. A kutatás online kérdőív segítségével vizsgálta a PhD-fokozattal rendelkezôk mobilitását: karrierjét, munkaszerződését, munka és magánéletének egyensúlyát, jövőterveit, valamint a fokozat hasznosíthatóságát. Eredményeink azt mutatják, hogy a férfiak külföldi munkaeröpiaci helyzete előnyösebb a nőkéhez képest, a munka-magánélet egyensúlya kihívás a nők számára, de mégis könnyebb külföldön, ugyanakkor a gyermekvállalásra negatív hatással van. A fokozatba fektetett tőkék megtérülését a férfiak egyértelmübben érzékelik, a nők elégedettsége mérsékeltebb.

KULCSSZAVAK: PhD-fokozat, nemzetközi mobilitás, magasan képzett migráció, karrier, nemek közötti esélyegyenlöség, munka-magánélet egyensúlya

\footnotetext{
${ }^{1}$ A kutatás a „Karriermodellek és karrierépítés a kutatás-fejlesztésben. Különbségek és egyenlőtlenségek a munkaerőpiaci lehetőségek, a személyes kapcsolathálók és a munka-magánélet egyensúlya tekintetében" címü NKFIH 116102 és 116099 konzorciális pályázat támogatásával készült. Ezúton szeretnénk köszönetet mondani Mátay Melindának a hólabdás kérdezés lebonyolításáért.

${ }^{2}$ Debreceni Egyetem, Bölcsészettudományi Kar, Politikatudományi és Szociológiai Intézet, Szociológiai és Szociálpolitikai Tanszék; fenyes.zsuzsanna@arts.unideb.hu

${ }^{3}$ Társadalomtudományi Kutatatóközpont Szociológiai Intézet; paksi.veronika@tk.mta.hu

${ }^{4}$ IBS Nemzetközi Üzleti Főiskola; Társadalomtudományi Kutatatóközpont Szociológiai Intézet; tardos.katalin@tk.mta.hu

${ }^{5}$ Kopp Mária Intézet a Népesedésért és Családokért; markosvaleria.90@gmail.com

${ }^{6}$ Debreceni Egyetem, Bölcsészettudományi Kar, Nevelés- és Művelődéstudományi Intézet; szigeti.fruzsina.89@gmail.com
} 


\section{KÖZELKÉP}

\section{ABSTRACT}

\section{Hungarian Academics Working Abroad: Female and Male Career Paths}

Transnational mobility has not only become an integral part of the successful, internatonally driven career path of academics, but is emerging to a great extent as a major performance requirement. Similarly to academic careers in general, international mobility of researchers is also a gendered process to a great extent. This paper aims to assess the most important characteristics of Hungarian researchers working abroad with special attention put on the similarities and differences identified in the career path of female and male researchers. With an online self-administered questionnaire distributed through a snowball sampling methodology among Hungarian PhD-holders working abroad for more than one year, we investigated the motivation for international mobility, the career path, work contracts, work-life balance, future career plans and the perception of the value of the PhD degree. Our key findings indicate that male researchers's labour market position is more advantageous abroad than female researchers' and overall they are more convinved of the positive value of their PhD degree, while female academics were statisfied, but at a more moderate level.

KEYWORDS: PhD degree, international mobility, migration of the highly qualified, career, gender equality, work-life balance

\section{Bevezetés}

A tudományos kiválóság egyre objektívebb mérőszámai - mint például a magas presztízsű folyóiratokban publikálás, konzorciális kutatócsoportok vezetése vagy az abban való részvétel - a kutatói munkát egyre erősebben kapcsolják a nemzetközi kutatási térhez, ami egyre nagyobb mértékben igényli a kutatók nemzetközi mobilitását (Abramo et al. 2009). Statisztikai adatok is alátámasztják, hogy a PhD-val rendelkezők más felsőfokú végzettségű társaikhoz képest sokkal mobilabbak a munkaerőpiacon, 15-30\%-uk dolgozott már más országban, és a mobilitástapasztalattal rendelkező kutatók nagyobb eséllyel tervezik az ismételt külföldi munkavállalást (OECD 2013). A nemzetközi mobilitás tehát jelentős mérföldkövévé vált a kutatói életútnak, és napjainkra már olyan erős elvárásként jelenik meg, hogy az európai intézményekben dolgozó kutatók közel 90 százaléka az álláskeresés és a szakmai előmenetel meghatározó tényezőjeként nevezi meg (European Commission 2017).

A tudományos karrierek azonban jelentősen meghatározottak a társadalmi nemek szerint (Xie - Shauman 2003). A nemek horizontális szegregációja már a felsőoktatásban jelentkezik, ahol a műszaki és természettudományi képzésekben a nők jelentősen kisebb arányban vannak jelen a férfihallgatókhoz képest. Ez a szegregáció a munkaerőpiacon tovább erősödik azáltal, hogy a műszaki és természettudományi végzettségű nők jelentős része vagy nem választja, vagy elhagyja a pályát - ez a jelenség az úgynevezett szivárgó vezeték metafora (leaky pipeline) (Berryman 1983). A pályaelhagyásnak számos oka van, a pályán maradó nőknek pedig a vertikális szegregációval is számolniuk kell: a nők szakmai előrehaladása lassabb a 


\section{KÖZELKÉP}

férfi kollégáikhoz képest, s jellemzően meg is akad egy bizonyos szint után - ez az úgynevezett üvegplafon jelenség (Xie - Shauman 2003), s ez kifejezetten igaz a magyar kutatónőkre is (Fényes 2018; Központi Statisztikai Hivatal 2011). A nők előtt álló akadályok összetettek, de a legmeghatározóbb tényezők a munka és magánélet egyensúlyának nehézségei, ami a nők gyermekvállalásával függ össze. A láthatatlan üvegplafon eredményeképpen a tudományos pályán dolgozó nők között kevesebb a PhD-fokozattal rendelkező és a döntéshozó pozíciókban levő, valamint sokkal több az elvált és a gyermektelen a férfi kutatókhoz képest (Mason et al. 2013).

Ahogyan a kutatók életútját, úgy az országokon átívelő mobilitását is számos tényező alakítja, ugyanakkor csak kevés - statisztikákon túlmutató - kutatás foglalkozik a témával (Bilecen - Van Mol 2017, González Ramos Bosch 2013). Pedig a mobilitást egyészt jelentősen befolyásolja a kutatási szektorban erősödő neoliberális és piacorientált verseny, valamint a kormányzati és az egyéb intézményi érdekek, melyek új tudás létrehozását tűzik ki célul a nemzetközi mobilitás és együttmúködések erősítése révén (Kim 2009, 2017). Márészt számos olyan strukturális és egyéni tényező formálja, mint például a karrierlehetőségek az egyes tudományterületeken, a jövedelmi vagy családi helyzet (OECD 2013). A külföldön dolgozó magyar diplomások csoportjának részletesebb vizsgálatát még kevesebb kutatás célozta meg (Csanády - Személyi 2006, Horváth - Kmetty 2008), és a legmagasabban képzettek magyarok külföldre áramló csoportjára, a PhD-val rendelkezőkre pedig tudomásunk szerint még nem fókuszált kutatás. Tekintettel arra, hogy a nemzetközi tudományos mobilitás csak az utóbbi évtizedekben növekedett meg jelentősen, arról is kevesebb tudással rendelkezünk, hogy a külföldi mobilitás milyen módon kapcsolódik össze az egyenlőtlenségek különböző típusaival. Bilecen és Van Mol (2017) annak a véleményének ad hangot, hogy mind a hozzáférés, mind a nemzetközi mobilitás kimeneteiben is megmutatkozhatnak az egyenlőtlenségek. A fokozattal rendelkezők életútjának vizsgálata egyrészt segítené az úgynevezett agyelszívás, vagy - napjainkra jellemzőbben - a cirkuláris mobilitás jelenségének megértését, a fokozatba fektetett tőkék megtérülését, a sikeres nemzetközi karrierek „titkát”, továbbá a nemi egyenlőtlenségek feltárása rávilágíthatna a nemek közöti egyenlőtlenségek további sajátosságaira, és segíthetné a nőket az akadályok leküzdésében.

Jelen tanulmány ezért a tartósan külföldön dolgozó magyar kutatók életútját elemzi a nemek közötti eltérő mintázatok szempontjából. Kutatási kérdésünket a következőképpen fogalmaztuk meg: A tartós (1 évnél hosszabb) nemzetközi mobilitásban résztvevő magyar kutatók körében milyen nemek közötti különbségek és egyenlőtlenségek tapasztalhatók a családösszetétel, a munka-magánélet összehangolása, a tudományos és munkahelyi előmenetel, valamint a PhD-fokozat megtérülésének szubjektív észlelése között? A kutatási adatokat online kérdőív segítségével gyűjtöttük össze 2019 során, hólabda módszerrel $(N=147)$. Hipotézisünk szerint a nők objektíve és szubjektíve is hátrányosabb helyzetben vannak a külföldre távozó magyar kutatók körében a férfiakhoz képest mind családösszetétel, munka- 


\section{KÖZELKÉP}

magánélet összehangolása, tudományos és munkahelyi előmenetel, valamint a PhDfokozat megtérülésének tekintetében. A tanulmány először a nemzetközi és hazai szakirodalmat tekinti át és mutatja be a magasan képzett migráció vonatkozó főbb jellemzőit, majd a módszertan és az eredmények ismertetése után a kutatás konklúzióját és továbbvitelét ismerteti.

\section{Szakirodalmi áttekintés}

\section{NEMZETKÖZI MOBILITÁS ÉS A KUTATÓI/TUDOMÁNYOS KARRIER}

A tudáselit elvándorlása, az úgynevezett agyelszívás (brain drain) már a 20. század közepétől vizsgált jelenség, amit csak a '90-es évektől nevez a szakirodalom leginkább képzett vagy diplomás migrációnak, nemzetközi mobilitásnak. Az agyelszívás mindig hullámokban jelenik meg, általában krízishelyzetek vagy jelentősebb gazdasági-társadalmi változások kísérőjelenségeként. Hatása lehet pozitív, amennyiben továbbtanulásra, továbbképzésre motiválja a munkaerőt (Stark et al. 1998), vagy elősegíti a nemzetközi tapasztalat megszerzését (Davenport 2004). Ugyanakkor jellemzően inkább negatív a megítélése: a tudáselit kivándorlásával elvész a tudásba befektetett tőke, ami szignifikánsan csökkenti az adott ország GDP-jét (Horváth Kmetty 2008). A '90-es évek felgyorsult gazdasági növekedése azonban egy új jelenséget hozott magával: az addig kivándorolt munkaerő részben hazaáramlását. A mobilitás már nem egy-, hanem többirányú, ismétlődő folyamat is lehet, amit a szakirodalom már cirkuláris mobilitásként nevez (Horváth - Kmetty 2008).

Az egyik legátfogóbb, nemzetközi mobilitást vizsgáló kutatás az európai uniós „MORE3” kutatás (European Commission 2017). A vizsgálat a célországokat vizsgálva kimutatta, hogy az eltérő gazdasági életszínvonal és az egyes országok tudományos intézményrendszerének fejlettsége közötti különbözőségéből adódóan az európai országok vonzósága nem egyforma, így a tartós nemzetközi mobilitás célországai jellemzően a magasabb jövedelmi színvonalat biztosító és fejlett kutatási infrastrukturális biztosító országok közül kerülnek ki. Jellemző a keletről nyugati irányba történő mozgás: ez az asszimmetria a mobilitás irányait tekintve fenntartja az agyelszívás és a „brain gain” folyamatait, ellentétben a kétirányú mozgás által megvalósítható, elvben nagyobb tudás létrehozását biztosító „brain circulation” (agykörforgás) folyamatával szemben (European Commission 2017). Az európai tudományos kutatók a legvonzóbb nemzetközi mobilitási célországoknak az Egyesült Államokat, és az európai, de az Európai Unión kívüli országokat, mint Izland, Norvégia és Svájc értékelték a legvonzóbbnak. A megkérdezett kutatók értékelése alapján az európai országok a legfejlettebb kutatási infrastruktúrával rendelkező országokhoz képest gyengébb értékelést kaptak a tudományos teljesítményt segítő munkakö- 


\section{KÖZELKÉP}

rülmények kialakítása, a karrierlehetőségek, a kutatási támogatások és a megfelelő kutatói munkakörök elérhetősége tekintetében (European Commission 2017).

A MORE3 projekt eredményei azt is kimutatták (European Commission 2017), hogy a PhD-fokozat megszerzésének időszakában a PhD-hallgatók és fiatal kutatók közel egyötöde vett részt nemzetközi mobilitásban (16\% külföldön tanult és 18\% volt több mint három hónapos külföldi munkán), de a PhD-tanulmányok nemzetközi helyszínére utazáson kívül kevéssé volt jellemző az azon túli nemzetközi mobilitás. Európai uniós átlagot tekintve nincsen különbség a férfi és női fiatal kutatók nemzetközi mobilitásában (17,7\% a férfiak és 18,8\% a nők esetében). Ugyanakkor országonként jelentős különbségek fordulhatnak elő: a spanyol fiatal kutatók körében a nők mobilabbak mint a férfiak (70,4\% és 37,7\%), míg Dániában vagy Belgiumban például a férfiak voltak a mobilabbak. Magyarországgal kapcsolatban csak a férfiakra vonatkozó adat áll rendelkezésre: a fiatal kutató férfiak 21,1\%-a volt mobil 2016ban (European Commission 2017).

A fiatal kutatók motivációjában legfontosabb a kiemelkedő tudósokkal való együttműködés lehetősége, a magas színvonalú képzéshez való hozzájutás, valamint a nemzetközi tapasztalatnak köszönhető szakmai előmeneteli lehetőségek voltak. A családi állapot meghatározó a PhD-szerzés időszakában a külföldi mobilitás motivációja tekintetében, de ennek hatása csökkenő jelentőségű, ha a partner/házastárs is tudományos kutató. Ugyanakkor, a kezdő kutatók kétharmada nem volt nemzetközileg mobil. A PhD időszakában a nemzetközi mobilitás legfontosabb akadályai között szerepeltek a személyes okok és a megfelelő pozíció/finanszírozás hiánya (European Commission 2017).

A posztdoktori nemzetközi mobilitásra vonatkozóan a MORE3-kutatás eredményei szerint az Európai Unióban a tudományos kutatók közel egyharmadáról (27\%) mondható el, hogy az elmúlt évtizedben három hónapnál több időt töltött külföldön. A hosszú távú tartós nemzetközi mobilitás általában kevésbé jellemző a dél- és kelet-európai országokban. A férfi és női posztdoktori kutatók körében fokozatosan csökkennek a különbségek a tartós nemzetközi mobilitás területén, de a családi összetétel továbbra is meghatározó. A női posztdoktor kutatók 25,1\%-a, míg a férfi posztdoktor kutatók 28,7\%-a volt három hónapnál hosszabb külföldi munkán a kérdezést megelőző 10 évben. A magyar posztdoktori kutatók körében az európai átlaghoz képest némileg magasabb volt a nemzetközi mobilitás aránya, de a férfi és női kutatók körében nem volt különbség (a posztdoktor nők 33,2\%-a, a férfiak 33,1\%-a volt mobil) (European Commission 2017).

A posztdoktorok körében a tartós nemzetközi mobilitás fő motivációja a nemzetközi networképítés, a szakmai előmenetel, illetve szintén a kiemelkedő tudósokkal való együttműködés lehetősége volt. Másfelől fő akadályai a nemzetközi mobilitásnak a megfelelő pozíció megtalálása, a földrajzi mobilitást és kutatást elősegítő pénzügyi erőforrások hiánya, illetve logisztikai problémák voltak. A megkérdezett kutatók a tartós nemzetközi mobilitás hatását pozitívan értékelték és összhangban 


\section{KÖZELKÉP}

voltak az eredeti motivációkkal: a nemzetközi networképítés, együttműködések kialakítása, valamint szakmai előmenetel. Tehát a tudományos kutatók általában a szakmai előmenetelüket szeretnék elősegíteni a nemzetközi mobilitás segítségével, és alapvetően személyes és családi okok vagy a megfelelő pozíció, forrás hiánya miatt döntenek a helyben maradás mellett (European Commission 2017).

\section{KÜLÖNBSÉGEK A FÉRFI ÉS NŐI KUTATÓK NEMZETKÖZI TARTÓS MOBILITÁSÁBAN}

Jöns (2011) Németországban a Humbold ösztöndíjasok körében vizsgálta meg a rövid idejű nemzetközi, ún. „cirkuláris” mobilitást és annak jellemzőit a nemek közötti egyenlőtlenségekkel kapcsolatban. A longitudinális vizsgálat kimutatatta, hogy a női kutatók országok közötti mobilitása növekszik, de alacsonyabb, mint férfi társaiké, fóképp a természettudományokban. Jöns kiemeli, hogy azok a kutatók, akik strukturális okok miatt nem tudnak részt venni a nemzetközi mobilitásban és tudáslétrehozásban, szisztematikus hátrányoknak vannak kitéve kutatói pályájukon, ezért is fontos, hogy az intézmények figyelemmel kövessék, hogy a nemzetközi mobilitási folyamatokban milyen egyenlőtlenségek fedezhetőek fel. Loeb (2006) a szakirodalom áttekintése után arra a következtetésre jutott, hogy a családi állapot hatása a teljesítményre nem teljesen egyértelmü, de a legfőbb mintázatok azért látszanak: a házas kutatók hatékonyabbak, mint a nem házasok, a kisgyermek jelenléte a családban negatív hatással van a nők teljesítményére, de a férfiakéra nem, a házas, ún. tenure pályán mozgó férfiak több időt tudnak a kutatásra fordítani, mint női kollégáik, akik szignifikánsan több időt töltenek háztartási munkával. A szerző ugyanakkor felhívja a figyelmet arra is, hogy az ösztöndíjak és egyéb szakmai teljesítmények elbírálási folyamatai elfogultak lehetnek, és a nők munkáját sokkal „keményebben” bírálják (Loeb 2006).

Schaer és munkatársai (2017) fiatal kutatópárok körében vizsgálták meg a nemzetközi mobilitással kapcsolatos egyeztetéseiket és kialakított megoldásaikat, amelyek során megpróbálják az intézményi és társadalmi struktúrák által rájuk kényszerített nemi viszonyokat feloldani. A szerzők amellett érvelnek, hogy a nemi viszonyok dinamikus természetűek és átalakulás alatt állnak, és nem feltétlenül biztos, hogy a „szivárgó vezeték” (leaky pipeline) metaforával leírt folyamat oksági kapcsolatba hozható a nemzetközi mobilitást egyre inkább elvárássá alakító intézményi struktúrákkal. Ugyanakkor a szerzők azt is kiemelik, hogy a szülővé válás sokszor a tradicionális nemi szerepekhez tereli vissza a párokat. Ennek ellenére egyre gyakoribbá válik, hogy a nők is a mobilitás elsődleges aktorává (primary movers) válnak, vagy nem kívánják automatikusan követni hozzátartozóként házastársukat (tied movers). Folyamatban van olyan új, mobilitással kapcsolatos partnermegoldások kialakítása, mint az „ingázó elsődlegesen mobil” (commuting primary mover), vagy az „ingázó követő házastárs” (cumminting tied mover) (Schaer et al. 2017). 


\section{KÖZELKÉP}

Cañibano és munkatársai (2016) spanyol PhD-fokozattal rendelkező kutatók nemzetközi mobilitását vizsgálták egy több mint 10 ezer fős mintán. Eredményeik azt mutatták, hogy a spanyol kutatónők mobilisabbak voltak férfi társaiknál, de a nemzetközi utak gyakorisága kisebb és a külföldi tartózkodás időtartama rövidebb volt, továbbá inkább a karrier korai szakasza során volt tapasztalható a nagyobb mobilitás, és a női kutatók az anyaországhoz közelebbi úticélokat valósítottak meg (Cañibano et al. 2016).

A szakirodalomban számos kutatás világított rá arra, hogy a nemzetközi mobilitási mintázatokra befolyással van a kutatók neme, családi állapota. Toader és Dahinden (2018) a posztdoktori kutatók tartós nemzetközi mobilitási trendjeit vizsgálták az UCLA, a Cambridge-i és a Zürichi Egyetemen kvalitatív módszerekkel. Arra mutattak rá, hogy a nemi szerepek sokkal differenciáltabbakká váltak a tradicionális modellnél, minthogy kizárólag a férfi kutató legyen az „elsődlegesen mobil” és a női partner/házastárs pedig a „kötötten” mozgó fél (tied mover). Ugyanakkor leszögezték, hogy a gyermekvállalás továbbra is jelentősen befolyásolja a nemi szerepeket, de arra hívták fel a figyelmet, hogy az intézmények családbarát politikája kifjezetten pozitívan befolyásolhatja a nemek közötti egyenlőség alakulását is (Toader - Dahinden 2018).

A szülői státusz, azaz a gyermek léte vagy nemléte a családban is meghatározóan hathat a karrierutakra, így a mobilitásra is. Uhly és szerzőtársai (2015) arra keresték a választ kutatásukban, hogy a családi feladatok mennyiben képeznek egy „üvegkerítést” (glass fence) a nők számára a nemzetközi együttműködésekben való részvételnél. Nemzetközi adatokat használva arra a következtetésre jutottak, hogy a nők kevésbé vesznek részt nemzetközi együttműködésekben. Bár mindkét partnerre pozitív hatással volt a tudományos karriert folytató házastárs, a férfiak többet profitáltak ebből. Ugyanakkor a partner foglalkoztatási státusza meghatározóbbnak bizonyult a nők nemzetközi együttműködésekben való részvételénél mint a gyerekek, tehát igazából az alkotta az „üvegkerítést” (Uhly et al. 2015).

A nők és a kisgyermekes családok nemzetközi mobilitását a szakmai okokon túl jelentősen befolyásolják az egyéni és családi szempontok, motivációk. FernandezZubieta és munkatársai (2013) tíz ország kutatóinak bevonásával vizsgálták a kutatók szakmai terveit, a döntéseik mögött húzódó motivációkat. Vizsgálatukban kiemelt szerepet kapott a különbözőségek feltárása a családi állapot és a társadalmi nemek alapján. Eredményeik azt mutatják, hogy a különböző mobilitási mintázatok mögött eltérő motivációk állnak, és a vizsgált dimenziók - családi állapot és társadalmi nem - szerepe kritikus a karriereket formáló döntésekben. A kisgyermekes szülőket nagy eséllyel befolyásolják a gazdasági okok (fizetés), biztonság és személyes okok. Ezen belül a férfi kutatókat inkább a gazdasági okok, a női kutatókat pedig a biztonság és személyes okok. Mindez arra utal, hogy a kutatók hajlamosak követni a tradicionális nemi szerepeket (Fernandez-Zubieta et al. 2013). 


\section{KÖZELKÉP}

González Ramos és Bosch (2013) mélyinterjúkon alapuló kutatása ugyanakkor a migráció pozitív hatását villantották fel tanulmányukban: vizsgálatukban a nemzetközi mobilitás a nők számára menekülést jelentett az otthoni kedvezőtlen munkahelyi körülményektől, ami akár segítheti nemcsak a szakmai karriert, de a családi életükben is kedvező változást hozhat. Ugyanakkor mindez megkívánja a szakmai és magánéletük nemcsak hosszútávú, de napi megtervezését. Azt is hangsúlyozták, hogy a megfelelő munka-magánélet egyensúly eléréséhez erős családi és intézményi támogatás, valamint megfelelő állami támogtás szükséges (González Ramos - Bosch 2013).

A felsőfokú végzettségűek körében gyakori jelenség a házassági homogámia, azaz ahol a partner, házastárs szintén felsőfokú végzettséggel rendelkezik (Paksi 2014). A kutatók esetében sok esetben a partner is kutatói karriert fut be - ez az ún. kettős akadémiai karrier - ezért a kutatópárok esetében felmerül a kérdés, hogyan tudják összeegyeztetni a két szakmai karriert a magánéletükkel, valamint egyforma eséllyel tudják-e építeni a karrierjüket. Vohlídalová (2014) a cseh kutatónők kapcsán vetette fel, hogy a politikák szintjén kevés figyelem fordul arra, hogyan hat a nemzetközi mobilitás a karrierekre, különösen a női életutakra. Kutatásában kutatópárok tartós mobilitását és családi életüket vizsgálta mélyinterjús módszerrel. Eredményei jól mutatják, hogy - általában a migráló kutató párjának - nagy lemondásokkal jár mind a privát, mint a családi életében. Kutatását azzal a konklúzióval zárja, hogy a kettős karrierek esetében az akadémiai mobilitás a társadalmi nemek által erősen meghatározott, mert a párok munkája és szakmai élete erősen egymásba fonódik (Vohlídalová 2014). Tzanakou (2017) tanulmányában úgy hívja fel a figyelmet a kettős karrierek problémájára, hogy három európai országban vizsgálta meg az egyetemeken újonnan indult „kettős karrier szolgáltatások”-at (dual career services). Az európai kezdeményezéseket az USA-ban már régebb óta működő szolgáltatásokkal hasonlította össze, hogy vajon azok tovább erősítik vagy inkább csökkentik a társadalmi nemek esélyegyenlőségét (Tzanakou 2017). Zippel (2011) pedig intézményi perspektívából vizsgálta a kettős karriereket, valamint hogy a jóléti államok menynyire befogadóak vagy kizáróak a gondoskodói munka irányában a kettős karrierek támogatása során (Zippel 2011). Acker (2004) pedig a témába irányuló kutatása eredményeképpen olyan konklúzióra jutott, ami a kettős karriereket a szivárgó metafora által is bemutatott jelenéhez köti: a kettős karrier magas fokú mobilitást generál, feszültséget szül a partnerek között, ami gyakran a nők pályaelhagyásához vagy lassabb szakmai előrehaladásához vezet (Ackers 2004). 


\section{KÖZELKÉP}

\section{MAGYAR KUTATÓK KÜLFÖLDÖN}

A külföldön dolgozó magyar diplomásokat mélyebben Személyi László és Csanády Márton (2011) vizsgálta. A két online adatfelvételükre válaszoló több mint 350 fó kifejezetten magasan kvalifikált volt, egynegyedük legalább két tudományterületen szerzett felsőfokú végzettséget, 10\%-uk rendelkezett PhD-fokozattal, és 4\%-uk volt a Magyar Tudományos Akadémia tagja. A legfőbb célország az USA, Anglia, Benelux államok és Németország volt, ahogyan ezt a fent említett OECD-adat is mutatta. A mintában felülreprezentáltak a jog, a közgazdaság és a természettudomány területén diplomát szerzettek. A migráció hátterében célként szintén a jobb anyagi helyzet és a munkahelyi karrier, elismertség állt, valamint a bizonytalan hazai politikai helyzet. Noha a megkérdezettek azt állították, hogy a külföldi kapcsolataik nem játszottak szerepet a döntéseikben, mégis majdnem felüknek volt rokona vagy barátja az adott országban. 40\%-uknak szándékában állt visszatérnie az anyaországba, egyharmaduk csak 10 év után, és 30\%-uk egyáltalán nem. Mindkét adatfelvételük azt erősítette meg, hogy minél több időt tartózkodik a munkavállaló külföldön, annál kisebb az esélye a hazatérésének. A mi kutatásunk szempontjából fontos eredménye, hogy a visszatérés esélye azok esetében volt nagyobb, akik ingatlannal rendelkeztek Magyarországon, akik öt évnél nem régebben mentek ki, és nem az oktatásikutatási szférában dolgoztak. A visszatérés esélyét azonban nem befolyásolta sem a házasság, sem a gyermekszám, sem az akkori kinti fizetés, sem pedig az, hogy a kiutazás előtt volt-e munkahelye vagy sem (Személyi - Csanády 2011: 42). A szerzőpáros végül arra is felhívta a figyelmet, hogy a külföldön dolgozó magyar kutatók alig tartanak kapcsolatot hazai szakmai szervezetekkel.

Tudomásunk szerint hazánkban eddig nem vizsgálták a külföldre vándorolt PhD-fokozattal rendelkezők csoportját. A Magyarországon dolgozó magasan képzettek e speciális csoportját azonban már több kutatás helyezte a kutatás fókuszába. Fábri György kérdőíves panelvizsgálata három hullámban vizsgálta a fokozattal rendelkezők attitűdjeit, a fokozat értékét, hasznosíthatóságát a munkaerőpiacon (Fábri 2018). Azt találta, hogy valamennyi szakterületen lényegesen alacsonyabb az anyagi, mint a szakmai megbecsültséggel való elégedettség, és az anyagi elégedettség a nők körében alacsonyabb, továbbá 2002 és 2014 között jelentősen megnőtt a fokozat előnyéről beszámolók aránya. Fényes Hajnalka egy kvantitatív kutatás másodelemzése során arra mutatott rá, hogy a vizsgált kutatók tudományos eredményessége nem tért el nemenként, de a nők hátrányos helyzete - vertikális szegregáció és a karrierlassulás a tudományos pályán - hangsúlyosan megjelent (Fényes 2018). Jelen tanulmány szerzői egy konzorciális kutatás keretében vegyes módszerekkel vizsgálják a fokozattal rendelkezők karrierjét, és egy most megjelent tanulmányban (Tardos - Paksi 2020) bemutatták, hogy a kutatók hogyan látják a saját és a másik nem karrierlehetőségeit, milyen segítő és akadályozó tényezőket azonosítanak a munkamagánélet egyensúly kapcsán, illetve léteznek-e esélyegyenlőséget elősegítő intéz- 


\section{KÖZELKÉP}

kedések, jó gyakorlatok a munkahelyeiken. A munka-magánélet egyensúlyával kapcsolatban mind a nők, mind a férfiak az egyéni megküzdési stratégiák, a szervezeti támogatási rendszerek és a társadalmi környezet, elvárások és attitűdök szintjén is megfogalmaztak véleményeket. A nők relatíve nagyobb arányban hangsúlyozták az egyéni megküzdési stratégiákat, míg a férfiak a társadalmi normákat, elvárásokat és attitűdöket. A kutatók továbbá kifejezetten tájékozatlanok voltak a lehetséges szervezeti támogató, humánpolitikai, esélyegyenlőségi, vagy családbarát intézkedések fontos szerepéről a munka-magánélet összehangolásában (Tardos - Paksi 2020).

\section{Módszertan és minta}

Kutatásunk alapsokaságát a tartósan - több mint egy éve - külföldön dolgozó PhDfokozattal rendelkező magyar kutatók alkotják. A teljes népesség nagyságát csak megbecsülni lehet, nincs pontos statisztika a jelenség természeténél fogva. A külföldre irányuló migrációs tendenciákról vannak kutatási adatok, de a használt módszertanokkal eltérő értékeket kapunk, a különbségek jelentősek, 120 és 637 ezer között mozognak (Blaskó et al. 2014, Központi Statisztikai Hivatal 2016). A teljes kutatói népesség 66 ezer főből állt 2018-ban (Központi Statisztikai Hivatal 2019).

A célzott személyek nehezen elérhető volta miatt a kutatásban a mintát hólabdás mintavétellel alakítottuk ki. A mintába kerüléshez mind a három alábbi kritériumnak egyszerre kellett érvényesnek lennie:

1. PhD/CSc-fokozattal rendelkezik (lehet Magyarországon vagy külföldön szerzett fokozat);

2. Magyarországon született és/vagy magyar állampolgár;

3. Legalább 1 éve külföldön (nem Magyarországon) dolgozik.

A hólabdás mintavétel során egyszerre több csatornán keresztül próbáltuk meg elérni a válaszadókat: az NKFIH-s kutatásunk más részeiben (fókuszcsoportok, egyéni interjúk) szereplő személyeket megkértük, hogy ismeretségi körükben terjesszék az online kérdőív elérhetőségét. Ezen felül a következő csoportok irányába terítettük a felkérő levelünket: Facebook, PhD-fokozattal rendelkezők, MTA Társadalomtudományi Kutatóintézet, USA magyar érdekeltségű tudósklubok, magyarországi doktori iskolák, Magyar Szociológiai Társaság, Nők a Tudományért Egyesület, Tárki, Magyar Pszichológiai Társaság, SOTE Magatartástudományi Intézet, Bergeni Egyetem magyar kutatói, CEU PhD-fokozattal rendelkezők, Magyar Kémikusok Egyesülete, Magyar Pszichiátriai Társaság, Jogi Informatikai Társaság, Neumann János Számítógép-Tudományi Társaság, Magyar Mérnöki Kamara, Semmelweis Rácz Károly Doktori Iskola - celluláris és molekuláris élettan, valamint elméleti és klinikai immunológia, BME telefonkönyv lista. 


\section{KÖZELKÉP}

A kutatás adatgyűjtési módszere az online kérdőív volt. 2019 áprilisa és októbere között zajlott az adatgyűjtés. Az online kérdőív fő témáihoz a következők tartoztak: motiváció a nemzetközi mobilitásra, a külföldi munkavállalás munkaerőpiaci és szakmai előnyei és hátrányai, a szakmai életutak alakulása, család, munka-magánélet, a saját karrier jövőképe és a pályaelhagyás, a PhD-fokozat szubjektív megtérülése.

Összesen 154 fő töltötte ki a kérdőívet, ebből 147 fő felelt meg a fenti hármas követelménynek. A kutatási minta nem reprezentatív, de elég nagy a fontosabb mintázatok feltárására, elemzésére. A minta alapmegoszlásai a következők: A mintában 60\% férfi és 40\% nő szerepel, összhangban azzal, hogy az össznépességben is kevesebb a PhD- vagy kandidátusi fokozattal rendelkező nő, mint férfi (Központi Statisztikai Hivatal 2011). Életkor szerinti megoszlást tekintve, a mintában szereplő PhD-fokozattal rendelkezők 30\%-a 40 év alatti és 70\% 40 év feletti életkorú volt. A nők valamivel fiatalabbak (a nők átlagéletkora 44 év, a férfiaké 47 év, bár a különbség éppen nem szignifikáns, $\mathrm{p}=0$,067), ami azzal függ össze, hogy a nők fokozatosan áramoltak be az oktatás legfelsőbb szintjeire és a tudományos életbe (Fényes 2018). Tudományterületek szerint a mintában szereplők 57\%-a a természet- és műszaki tudományok, 43\%-a társadalom- és bölcsészettudományok területén szerezte fokozatát. A minta összetételét a magyarországi kutatók csoportjához hasonlítva megállapíthatjuk, hogy a nők és a társadalom- és bölcsészettudományi területek felülreprezentáltak.

\section{Eredmények}

Az online kérdőívünkre beérkezett válaszok alapján jól látható, hogy a nemzetközi mobilitás célországai szignifikánsan különböznek a nők és a férfiak körében. A jelenlegi lakóhely tekintetében az EU-tagállamból több nő, az USA-ból kicsit több férfi válaszolt kérdőívünkre (1. táblázat). Úgy tűnik, hogy a magyar kutatónők körében vonzóbbak a közelebbi, európai desztinációk, mint ahogyan az Cañibano és munkatársai (2016) kutatásában is megfigyelhető volt, amikor spanyol PhD-fokozattal rendelkező kutatók nemzetközi mobilitását vizsgálva kimutatták, hogy a spanyol kutatónők egyrészt mobilisabbak voltak férfi társaiknál, másrészt az anyaországhoz közelebbi úticélokat valósítottak meg (Cañibano et al. 2016). További magyarázó ok lehet a választott desztinációk eltérő mintázatára nők és férfiak között, hogy a természet- és műszaki tudományterületeken dolgozók szignifikánsan nagyobb arányban választják az USA-t mint úticélt (31\%) a társadalomtudományi területekhez képest (13\%), és jól ismert adat, hogy a természet- és műszaki tudományterületeken felülreprezentáltak a férfiak (Xie-Shauman 2003). 


\section{KÖZELKÉP}

1. táblázat. Jelenlegi lakóhely nemek szerint (\%)

\begin{tabular}{|l|c|c|c|}
\hline & Férfi & Nő & Összesen \\
\hline EU-tagállam & 52 & $\underline{74}$ & 66 \\
\hline USA & 29 & 16 & 24 \\
\hline Egyéb ország & 19 & 10 & 16 \\
\hline Összesen & $100 \%$ & $100 \%$ & $100 \%$ \\
N & 89 & 58 & 147 \\
\hline
\end{tabular}

Az aláhúzva szereplő értékeknél az adjusted reziduals abszolút értéke nagyobb, mint kettő. (Khi-négyzet próba, p = 0,012) Forrás: Saját szerkesztés

\section{A FÉRFIAK ÉS NŐK TÁRSADALMI ÉS CSALÁDI HÁTTERE}

A férfiak és a nők anyagi helyzete nem tért el szignifikánsan a mintában, mint ahogy a születéskori településtípus, a szülők iskolázottsága és tudományos fokozata, valamint a fokozatok tudományterülete sem. A családi állapotnál a szakirodalommal összhangban (Fényes 2018), az adjusted reziduals értékek szerint több a házas, házastárssal élő férfi (72\%), mint nő (56\%), bár összességében az eredmény nem szignifikáns. A házastárs iskolai végzettsége, tudományos fokozata és annak tudományterülete sem tért el a megkérdezettek neme szerint.

Azonban a gyerekszámban már szignifikáns eltérés volt megfigyelhető a külföldön élő, fokozattal rendelkezők körében: a nők felülreprezentáltak a gyermektelenek és az egygyerekesek, míg a férfiak a háromgyerekesek körében (2. táblázat). Hangsúlyoznunk kell, hogy a kutatónők körében a gyermektelenség szignifikánsan magasabb, mint a férfikutatók körében (46\% kontra 23\%), valamint további érdekes adat, hogy míg a 40 év alatti fiatal kutatóknál nincsen még különbség abban, hogy van-e vagy nincs gyermeke - mind a férfi és női kutatók egyharmadának van gyermeke és kétharmadának nincsen - ezzel szemben a 40 év feletti korosztályban az olló kinyílik a férfiak és nők között: a férfiak 9\%-ának nincs csak gyermeke, míg a 40 év feletti kutatónők több mint egyharmada (!) gyermektelen (34\%). Ezek az eredmények összhangban vannak a nemzetközi kutatási eredményekkel, miszerint a férfiak jobban össze tudják egyeztetni a munkájukat és családi életüket, és a gyermekvállalás a nők számára nagyobb kihívás a tudományos pályán, mint férfi kollégáik számára (Mason et al. 2013). 
www. metszetek.unideb.hu

\section{KÖZELKÉP}

2. táblázat. Gyermekek száma nemenként (\%)

\begin{tabular}{|l|c|c|c|}
\hline & Férfi & Nő & Összesen \\
\hline Egy gyermek & 23 & $\underline{56}$ & $\underline{34}$ \\
\hline Kettő gyermek & 52 & 38 & 48 \\
\hline Három gyermek & $\underline{19}$ & 3 & 14 \\
\hline Háromnál több gyermek & 6 & 3 & 5 \\
\hline Összesen & $100 \%$ & $100 \%$ & $100 \%$ \\
\hline N & 69 & 32 & 101 \\
\hline
\end{tabular}

Az aláhúzva szereplő értékeknél az adjusted reziduals abszolút értéke nagyobb, mint kettő. (Khi-négyzet próba, p = 0,005) Forrás: Saját szerkesztés

\section{TANULMÁNYOK, TUDOMÁNYOS FOKOZATOK}

A megkérdezettek 10-20\%-a több MA/MSc diplomával rendelkezett, és ebben nem volt eltérés a nemek között, vagyis a több lábon állás, a több diplomával való rendelkezés nem jellemzőbb a mintában szereplő nőkre a férfiakhoz képest. Nem volt eltérés továbbá a nyelvtudás tekintetében sem, illetve abban sem, hogy milyen tagozaton és finanszírozási formában végezték a PhD-képzést. A PhD-képzés tudományterülete azonban szignifikánsan eltért nemenként (3. táblázat), ami visszatükrözi a hazai tudományos élet horizontális szegregációját, miszerint a természettudományokban a férfiak, míg a társadalom- és bölcsésztudományban a nők felülreprezentáltak (Fényes 2018).

3. táblázat. A PhD-fokozatok tudományterületi megoszlása nemek szerint (\%)

\begin{tabular}{|l|c|c|c|}
\hline & Férfi & Nő & Összesen \\
\hline Természettudományok & $\underline{50}$ & 20 & 38 \\
\hline Műszaki tudományok & 11 & 7 & 9 \\
\hline Orvostudományok & 9 & 4 & 7 \\
\hline Agrártudományok & 1 & 4 & 2 \\
\hline Társadalomtudományok & 16 & $\underline{33}$ & 23 \\
\hline Bölcsészettudományok & 13 & $\underline{31}$ & 20 \\
\hline Művészetek & 0 & 0 & 0 \\
\hline Hittudomány & 0 & 2 & 1 \\
\hline Összesen & $100 \%$ & $100 \%$ & $100 \%$ \\
N & 86 & 55 & 141 \\
\hline
\end{tabular}

Az aláhúzva szereplő értékeknél az adjusted reziduals abszolút értéke nagyobb, mint kettő.

(Khi-négyzet próba, p=0,003) Forrás: Saját szerkesztés 


\section{KÖZELKÉP}

A kandidátusi fokozatban és a habilitációban, valamint azok tudományterületében nem tapasztaltunk különbséget nemek szerint. Viszont a DSc, azaz az MTA doktora) címet megvizsgálva már megjelent a vertikális szegregáció nemenként: míg a férfiak 30\%-a, addig a nők csak 9\%-a rendelkezett vele (4. táblázat).

4. táblázat. DSc (MTA doktora) címmel rendelkezők aránya nemek szerint (\%)

\begin{tabular}{|l|c|c|c|}
\hline & Férfi & Nő & Összesen \\
\hline Rendelkezik & $\underline{30}$ & 9 & 22 \\
\hline Nem rendelkezik & 70 & $\underline{91}$ & $\underline{78}$ \\
\hline Összesen & $100 \%$ & $100 \%$ & $100 \%$ \\
$\mathrm{~N}$ & 76 & 45 & 121 \\
\hline
\end{tabular}

Az aláhúzva szereplő értékeknél az adjusted reziduals abszolút értéke nagyobb, mint kettő. (Khi-négyzet próba, p = 0,006) Forrás: Saját szerkesztés

\section{MUNKAHELYI KARRIER}

A megkérdezettek legfontosabb magyarországi munkahelyének típusa, régiója, jellege nem tért el nemenként. Abban azonban, hogy mi motiválta a magyar kutatókat a jelenlegi külföldi munkavállalásra, hat esetben találtunk szignifikáns eltérést. Az 5. számú táblázat alapján jól látható, hogy a kedvezőbb megélhetési feltételek és magasabb jövedelem ( $p=0,026)$, a szakmai előrejutási lehetőség $(p=0,012)$, a kihívás $(p=0,008)$ és a tapasztalatszerzés $(p=0,004)$ a férfiakat jobban motiválta, mint a nőket, ami összhangban van a hagyományos nemi szerepekkel. Ezt erősíti az is, hogy mintánkban a női kutatók szignifikánsan gyakrabban említették, hogy ők követték házastársukat/partnerüket külföldre (tied movers) ( $p=0,000)$, illetve a családi és magánéleti okokra is gyakrabban hivatkoztak, amelyek valószínúleg szintén részben a partnerrel való együttmozgásra utalnak $(\mathrm{p}=0,004)$. Az eredményeink megerősítik, hogy a magyar kontextusban is jelentősek maradnak a tradicionális nemi szerepek, és ennek megfelelően tipikusabb jelenség, hogy a kettős kutatói párok közül a nők követik partnerüket a külföldi munkavállalás során (Ackers 2004, Tzanakou 2017). Másfelől fontos látni azt is, hogy a férfi és női kutatók a nemzetközi mobilitás motivációjaként ugyanabban a sorrendben említették az első öt leggyakoribb tényezőt (5. táblázat). 


\section{KÖZELKÉP}

6. táblázat. A nemzetközi mobilitás motivációja nemek szerint (\%)

\begin{tabular}{|l|c|c|}
\hline & Férfi & Nő \\
\hline Kedvezőbb munkakörülmények & 53 & 47 \\
\hline $\begin{array}{l}\text { Kedvezőbb megélhetési feltételek, magasabb jöve- } \\
\text { delem }\end{array}$ & 58 & 40 \\
\hline Szakmai előrejutási lehetőség & $\underline{54}$ & 33 \\
\hline Kihívás & $\underline{49}$ & 28 \\
\hline Tapasztalatszerzés & $\underline{46}$ & 22 \\
\hline Házastárs/partner követése külföldre & 2 & 19 \\
\hline Szakmájában nem tudott elhelyezkedni itthon & 14 & 17 \\
\hline Család, magánéleti okok & 3 & 17 \\
\hline Kényszerhelyzet & 17 & 14 \\
\hline Vonzó állásajánlat & 3 & 9 \\
\hline Nyelvtanulás & 16 & 5 \\
\hline Nemzetközi pályázatban való részvétel miatt & 7 & 5 \\
\hline Politikai helyzet & 6 & 3 \\
\hline Szervezeti átalakítások, bizonytalanságok & 2 & 3 \\
\hline
\end{tabular}

Az aláhúzva szereplő értékeknél az adjusted reziduals abszolút értéke nagyobb, mint kettő. Forrás: Saját szerkesztés

A vizsgálatban résztvevő kutatók jelenlegi külföldi munkaszerződésének jellegében szignifikáns eltérés mutatkozott nemenként. A férfiak nagyobb arányban (49\%) kaptak azonnal, a foglalkoztatás elején határozatlan idejű szerződést, mint a nők (40\%). Ezzel összhangban látható, hogy a határozatlan, de az elején határozott idejű munkaviszony a nőkre volt jellemzőbb. Másfelől, az egy évnél rövidebb határozott munkaszerződés pedig a férfiaknál volt inkább jellemző, amely jelenség egyik lehetséges értelmezése, hogy a nők a külföldi munkavállalás kapcsán nagyobb biztonságra törekednek, és csak biztosabb munkavállalási feltételek esetén vállalják azt. Összességében vizsgálva viszont elmondható, hogy a külföldön dolgozó magyar kutatók kétötöde határozott idejű szerződéssel dolgozik, ami mindkét nem bizonytalanabb munkaerőpiaci pozíciójára utalhat (6. táblázat). 
www. metszetek.unideb.hu

\section{KÖZELKÉP}

7. táblázat. A munkaszerződés jellege nemek szerint (\%)

\begin{tabular}{|l|c|c|c|}
\hline & Férfi & Nő & Összesen \\
\hline Határozatlan idejü (mindig is az volt) & 49 & 40 & 46 \\
\hline Határozatlan idejű (de az elején határozott volt) & 10 & $\underline{21}$ & 14 \\
\hline Határozott idejü (egy évnél rövidebb) & $\underline{9}$ & 0 & 5 \\
\hline Határozott idejű (egy évnél hosszabb) & 33 & 39 & 35 \\
\hline Összesen & $100 \%$ & $100 \%$ & $100 \%$ \\
N & 78 & 52 & 134 \\
\hline
\end{tabular}

Az aláhúzva szereplő értékeknél az adjusted reziduals abszolút értéke nagyobb, mint kettő. (Khi-négyzet próba, $\mathrm{p}=0,043$ ) Forrás: Saját szerkesztés

Az elemzés során kitértünk a vezető beosztások vizsgálatára is. Itt további különbségek rajzolódtak ki a nemek között, azaz a vertikális szegregáció nemcsak a nagydoktori cím, de a vezető pozíció gyakoriságában is megmutatkozik. Noha a különbségek statisztikailag nem szignifikánsak, érdemes jelezni, hogy amíg a férfiak 38\%-a, addig a nők 23\%-a tölt be vezető pozíciót jelenlegi külföldi munkahelyén (7. táblázat).

8. táblázat. Vezető beosztásban dolgozó kutatók aránya nemek szerint (\%)

\begin{tabular}{|l|c|c|c|}
\hline & Férfi & Nő & Összesen \\
\hline Vezető beosztásban dolgozik & 38 & 23 & 32 \\
\hline Nem vezető beosztásban dolgozik & 62 & 77 & 68 \\
\hline Összesen & $100 \%$ & $100 \%$ & $100 \%$ \\
N & 84 & 53 & 137 \\
\hline
\end{tabular}

Az aláhúzva szereplő értékeknél az adjusted reziduals abszolút értéke nagyobb, mint kettő. (Khi-négyzet próba, $\mathrm{p}=0,059$ ) Forrás: Saját szerkesztés

A munkaerőpiaci helyzet alaposabb feltárása céljából a kérdőívben rákérdeztünk a jelenlegi másodállás és a magyar, illetve külföldi munkanélküliség helyzetére is. A másodállás és a magyarországi munkanélküliség hasonló arányban fordult elő a férfiak és nők körében, viszont külföldi munkanélküliséget a nők éltek meg gyakrabban (a nők 31\%-a, a férfiak 14\%-a) (8. táblázat). Azaz a kutatásunkban megkérdezett nők majdnem egyharmada volt már munkanélküli külföldön, s ez az arány több mint kétszerese a megkérdezett férfiakénak. Ez az eredményünk viszont már kifejezetten a nők hátrányosabb külföldi munkaerőpiaci helyzetét tükrözi. 


\section{KÖZELKÉP}

9. táblázat. A külföldi munkanélküliség előfordulási gyakorisága nemek szerint (\%)

\begin{tabular}{|l|c|c|c|}
\hline & Férfi & Nő & Összesen \\
\hline Volt munkanélküli & 14 & $\underline{31}$ & 21 \\
\hline Nem volt munkanélküli & $\underline{86}$ & 69 & 80 \\
\hline Összesen & $100 \%$ & $100 \%$ & $100 \%$ \\
N & 88 & 58 & 146 \\
\hline
\end{tabular}

Az aláhúzva szereplő értékeknél az adjusted reziduals abszolút értéke nagyobb, mint kettő. (Khi-négyzet próba $\mathrm{p}=0,011$ ) Forrás: Saját szerkesztés

A kutatás során arra is kíváncsiak voltunk, hogy a külföldre távozó PhD-fokozattal rendelkezők mennyire végeznek tudományos tevékenyéget, illetve mennyiben jellemző rájuk a pályaelhagyás. Az elemzés nem mutatott ki eltérést nemek szerint az oktatási és a kutatási feladatok gyakorisága kapcsán, ahogyan a publikációk típusában sem voltak különbségek (idegennyelvű, scopus és impact faktoros publikációk aránya). Abban azonban, hogy hány projekt vezetője volt a megkérdezett, szignifikáns különbség mutatkozott nemenként $(p=0,032)$. A férfiak átlagosan 2,0 , a nők pedig csak 1,2 projektnek voltak a vezetői, ami megint csak a vertikális szegregáció jelenlétére utal.

Az anyagi helyzet, a DSc cím megszerzése, az oktatói-kutatói tevékenység végzése és a vezetői pozíció betöltése alapján klaszteranalízist végeztünk. A klaszterelemzéssel három csoport rajzolódott ki:

- Az első, legnagyobb csoportba (59\%) tartozók oktatói és kutatói tevékenységet végeznek, de a többség nem rendelkezik DSc-fokozattal, nincsenek vezető pozícióban és az anyagi helyzetük inkább közepes az adott ország átlagához képest.

- A második, legkisebb csoportba (12\%) tartozók is alig rendelkeznek DSc-fokozattal, ráadásul nem oktatnak és nem kutatnak munkahelyükön, emellett alig jellemző rájuk a vezető pozíció. Ilyen formában pályaelhagyóknak tekinthetjük őket. Ugyanakkor egy kicsit jobb anyagi helyzetűek, mint az előző csoportba tartozók.

- A harmadik (közepes nagyságú) csoport (29\%) tagjai rendelkeznek a legjobb anyagi helyzettel, ők végeznek oktatói és kutatói tevékenységet, vezető beosztásban vannak, és sokan rendelkeznek DSc-fokozattal is.

Női-férfi bontásban vizsgálva a külföldön dolgozó, PhD-fokozattal rendelkezők mintáját, a nők hátrányosabb külföldi munkaerőpiaci és anyagi helyzete vált láthatóvá. Az erdmények azt mutatják, hogy a férfiak szignifikánsan nagyobb gyakorisággal vannak jelen a harmadik csoportban, több mint egyharmaduk jó anyagi helyzetü, 


\section{KÖZELKÉP}

vezető beosztású, magas fokozattal rendelkező oktató-kutató. A pályaelhagyás azonban hasonló gyakoriságú a külföldön dolgozó, PhD-val rendelkező férfiak és nők között, viszont azok körében, akik házastársukat „követték” a nemzetközi mobilitásban (tied movers), szignifikánsan magasabb volt a pályaelhagyás (31\%) (9. táblázat).

10 táblázat. A karriertípusok megoszlása nem szerint (\%)

\begin{tabular}{|l|c|c|c|}
\hline & Férfi & Nő & Összesen \\
\hline Közepes anyagi helyzetű oktató-kutatók & 53 & 69 & 59 \\
\hline Közepes anyagi helyzetű pályaelhagyók & 11 & 14 & 12 \\
\hline $\begin{array}{l}\text { Jó anyagi helyzetű, vezető beosztású, magas } \\
\text { fokozattal rendelkező oktató kutatók }\end{array}$ & $\underline{36}$ & 17 & 29 \\
\hline $\begin{array}{l}\text { Összesen } \\
\text { N }\end{array}$ & $\begin{array}{c}100 \% \\
89\end{array}$ & $\begin{array}{c}100 \% \\
58\end{array}$ & $\begin{array}{c}100 \% \\
147\end{array}$ \\
\hline
\end{tabular}

Az aláhúzott értékeknél az adjusted reziduals értéke nagyobb, mint 2, azaz több eset esik, mint ami a véletlen elrendezésből következne. (Khi-négyzet szign. = 0,033)

Forrás: Saját szerkesztés

\section{A MUNKA ÉS MAGÁNÉLET ÖSSZEHANGOLÁSA}

A munka és magánélet összehangolásával kapcsolatban - a várakozásokkal és a fenti eredményekkel szemben - nemenként nem volt eltérés egyik kérdésnél sem. A külföldön dolgozó PhD- vagy kandidátusi fokozattal rendelkezők általában elégedettek voltak e két terület összehangolásával: a döntő többség az „inkább elégedett vagyok” (43\%) és a „teljes mértékben elégedett vagyok” (42\%) választ jelölte meg. A válaszok alapján arra lehet következtetni, hogy aki nő létére eljut a tudományos élet ezen szintjére, külföldön dolgozva nem érzékel több problémát, mint férfi kollégái, vagy legalábbis nem ad neki hangot. A munkát a magánélettel, a családi feladatokkal és a gyerekvállalással a megkérdezettek 82-85\%-a tudja inkább igen vagy teljes mértékben összeegyeztetni, nemektől függetlenül. Azonban a válaszok alapján úgy tűnik, hogy az összehangolás könnyebb külföldön, mint Magyarországon, mert a válaszadók 16\%-a Magyarországon, 84\%-a külföldön (ahol most él) tartja jobban összeegyeztethetőnek a munkát és a magánéletet a saját szakmájában. Azonban annál a kérdésnél, hogy általában mennyire lehetséges az egyensúly megteremtése egy nő és egy férfi számára külföldön, a megkérdezettek, nemüktől függetlenül, azt a választ adták, hogy a nők számára nehezebb. A nők esetében 38\%-ban teljesen, 54\%ban többé-kevésbé, míg a férfiak számára 44\%-ban teljesen és 50\%-ban többé-kevésbé megvalósítható a munka és a magánélet összehangolása a kérdezettek szerint.

A párkapcsolatban élők partnerhez viszonyított szakmai karrierjének megítélésében szignifikáns eltérés volt nemek szerint. A férfiak nagyobb arányban mondták, 


\section{KÖZELKÉP}

hogy inkább vagy teljesen az ő karrierjük van előtérben a párjukéhoz képest (46\% kontra $15 \%$ a nőknél), tehát tudatában vannak a jobb helyzetüknek, a nők viszont többen mondták, hogy egyformán előtérben van a két karrier (70\%), vagy inkább párjuk karrierje van előtérben (15\%) (10. táblázat).

11. táblázat. A szakmai karrierek megítélése a házas-/élettárshoz viszonyítva, nemek szerint (\%)

\begin{tabular}{|l|c|c|c|}
\hline & Férfi & Nő & Összesen \\
\hline Az enyém van teljesen előtérben & 20 & 9 & 16 \\
\hline Inkább az enyém van teljesen előtérben & $\underline{26}$ & 6 & 18 \\
\hline $\begin{array}{l}\text { Egyformán fontos mindkettő, és ezt egyszerre } \\
\text { tudjuk... }\end{array}$ & 38 & $\underline{55}$ & 44 \\
\hline $\begin{array}{l}\text { Egyformán fontos mindkettő, de csak időben } \\
\text { eltolva... }\end{array}$ & 16 & 15 & 16 \\
\hline Inkább a páromé van előtérben & 0 & $\underline{9}$ & 4 \\
\hline A páromé van teljesen előtérben & 0 & $\underline{6}$ & 2 \\
\hline $\begin{array}{l}\text { Összesen } \\
\mathrm{N}\end{array}$ & $\begin{array}{c}100 \% \\
80\end{array}$ & $\begin{array}{c}100 \% \\
53\end{array}$ & $\begin{array}{c}100 \% \\
133\end{array}$ \\
\hline
\end{tabular}

Az aláhúzva szereplő értékeknél az adjusted reziduals abszolút értéke nagyobb, mint kettő. (Khi-négyzet próba, $\mathrm{p}=0,000$ ) Forrás: Saját szerkesztés

\section{JÖVŐTERVEK ÉS ELÉGEDETTSÉG}

A vizsgálat végezetül feltérképezte a külföldön dolgozók jövőterveit is. A jövőtervekben az esetleges magyarországi visszatérés vagy vissza nem térés okainál a nők többen hivatkoztak családi okokra, és a vissza nem térés okainál a különbség szignifikáns nemek szerint (11. táblázat).

12. táblázat. A családi okok, mint visszatartó erő a magyarországi visszatérésre nemek szerint (\%)

\begin{tabular}{|l|c|c|c|}
\hline & Férfi & Nő & Összesen \\
\hline Nem választotta & $\underline{79}$ & 59 & 71 \\
\hline Családi okok & 21 & $\underline{41}$ & 29 \\
\hline Összesen & $100 \%$ & $100 \%$ & $100 \%$ \\
N & 89 & 58 & 147 \\
\hline
\end{tabular}

Az aláhúzva szereplő értékeknél az adjusted reziduals abszolút értéke nagyobb, mint kettő. (Khi-négyzet próba, $\mathrm{p}=0,009$ ). Forrás: Saját szerkesztés 


\section{KÖZELKÉP}

A jelenlegi munkahellyel való elégedettséget vizsgálva, a férfiak inkább „teljesen" elégedettek voltak helyzetükkel, mint a nők, összhangban a fentebb bemutatott eredményeinkel (pl. hogy többen töltenek be vezető pozíciót, jobbak az anyagi körülményeik). Azonban fontos hangsúlyozni, hogy a kutatásunkban részt vett, külföldön dolgozó magyar PhD-fokozattal rendelkezők döntő többségében inkább elégedettek munkaerőpiaci helyzetükkel (12. táblázat).

13. táblázat. Munkaerőpiaci helyzettel való elégedettség nemek szerint (\%)

\begin{tabular}{|l|c|c|c|}
\hline & Férfi & Nő & Összesen \\
\hline Teljes mértékben & $\underline{48}$ & 30 & 41 \\
\hline Inkább igen & 39 & 46 & 41 \\
\hline Inkább nem & 13 & 21 & 16 \\
\hline Egyáltalán nem & 1 & 4 & 2 \\
\hline Összesen & $100 \%$ & $100 \%$ & $100 \%$ \\
N & 88 & 57 & 145 \\
\hline
\end{tabular}

Az aláhúzva szereplő értékeknél az adjusted reziduals abszolút értéke nagyobb, mint kettő. (Khi-négyzet próba, $\mathrm{p}=0,129$ ) Forrás: Saját szerkesztés

Fábri György korábbi kutatási eredményei azt mutatták, hogy a PhD-fokozattal rendelkezők több mint 70\%-ának anyagi és egzisztenciális szempontból is megérte fokozatot szerezni (Fábri 2018). Jelen kutatásban még magasabb ez az arány (81\%), de a figyelmet inkább a nemek szerinti különbségekre irányítjuk. A PhD- és kandidátusi fokozat megtérülésének értékelésénél is nemi véleménykülönbségek mutatkoztak: anyagi és egzisztenciális szempontból a férfiak többen voltak teljes mértékben elégedettek a fokozat megtérülésével, de érdekes, hogy a teljes mértékben elégedetlenek körében is felülreprezentáltak. A nők ellenben nagyobb arányban érezték, hogy ebből a szempontból inkább nem érte meg fokozatot szerezni (13. táblázat).

14. táblázat. A PhD(CSc)-fokozat megítélése anyagi, egzisztenciális szempontból nemenként $(\%)$

\begin{tabular}{|l|c|c|c|}
\hline & Férfi & Nő & Összesen \\
\hline Igen, teljes mértékben megérte & $\underline{56}$ & 33 & 47 \\
\hline Igen, inkább megérte & 30 & 41 & 34 \\
\hline Nem, inkább nem érte meg & 7 & $\underline{26}$ & 14 \\
\hline Nem, egyáltalán nem érte meg & $\underline{8}$ & 0 & 5 \\
\hline Összesen & $100 \%$ & $100 \%$ & $100 \%$ \\
N & 88 & 58 & 146 \\
\hline
\end{tabular}

Az aláhúzva szereplő értékeknél az adjusted reziduals abszolút értéke nagyobb, mint kettő. (Khi-négyzet próba, $\mathrm{p}=0,000$ ) Forrás: Saját szerkesztés 


\section{KÖZELKÉP}

Amikor a fokozat értékének megtérülését a szakmában való elhelyezkedés és a munkaerőpiaci pozíciók javítása szempontjából elemeztük, szintén azt találtuk, hogy bár alapvetően mindkét nem elégedett, a nők számára mégis kevésbé térült meg a befektetés, mint a férfiak számára. Ez ugyanúgy összhangban lehet azzal, hogy a nők körében kevesebben töltöttek be vezető pozíciót a vizsgálat időpontjában (14. táblázat).

15. táblázat. A PhD-fokozat megítélése a szakmában való elhelyezkedés és a munkaerőpiaci helyzet javítása szempontból nemek szerint (\%)

\begin{tabular}{|l|c|c|c|}
\hline & Férfi & Nő & Összesen \\
\hline Igen, teljes mértékben megérte & 66 & 52 & 61 \\
\hline Igen, inkább megérte & 26 & 25 & 25 \\
\hline Nem, inkább nem érte meg & 4 & $\underline{21}$ & 11 \\
\hline Nem, egyáltalán nem érte meg & 5 & 2 & 4 \\
\hline Összesen & $100 \%$ & $100 \%$ & $100 \%$ \\
N & 86 & 56 & 142 \\
\hline
\end{tabular}

Az aláhúzva szereplő értékeknél az adjusted reziduals abszolút értéke nagyobb, mint kettő. (Khi-négyzet próba, $\mathrm{p}=0,006$ ) Forrás: Saját szerkesztés

\section{Összegzés}

Tanulmányunk a PhD-fokozattal rendelkező, tartósan - több mint egy éve - külföldön dolgozó magyar kutatókat vizsgáltuk a nemzetközi mobilitás motivációja, a családösszetételük, a munka-magánélet összehangolásának sikeressége, a tudományos és munkahelyi előmenetel és a PhD-fokozatszerzés megtérülésének szubjektív észlelése tekintetében, elsősorban a nemek közötti hasonlóságokat és különbségeket állítva az elemzésünk középpontjába. Kutatásunkban arra kerestük a választ, hogy milyen nemek közötti különbségeket és egyenlőtlenségeket tapasztalunk a családösszetétel, a munka-magánélet összehangolása, a tudományos és munkahelyi előmenetel, valamint a PhD-fokozatszerzés megtérülésének szubjektív észlelése között? Eredményeinkkel szeretnénk hozzájárulni ahhoz a tágabb kérdéshez is, hogy vajon a női és férfi kutatók tartós nemzetközi mobilitása esélyt jelent-e a férfi és női kutatók közötti hagyományos egyenlőtlenségek - mint a horizontális és vertikális szegregáció - csökkentésére?

A mintában a megkérdezettek majdnem kétharmada férfi, és a férfiak átlagosan idősebbek a nőkhöz képest. Mindezek összhangban vannak azzal, hogy a nők csak fokozatosan áramoltak be a tudományos életbe, és az idősebb kutatói generációban 


\section{KÖZELKÉP}

több a férfi, mint a nő. Viszont a fiatalabb korosztályoknál a külföldön dolgozók körében kiegyenlítődni látszik a nemzetközi mobilitás gyakorisága: a 40 év alattiaknál fele-fele arányban szerepelnek a nők és a férfiak. A társadalmi háttér vizsgálata során az anyagi helyzetben, a szülők iskolázottságában és tudományos fokozataiban nem volt eltérés a férfiak és nők között. A férfiak és nők családi háttere azonban eltérő volt, összhangban Fényes (2018) eredményeivel. A kutatásunkban szereplők döntő többségében egyformán elégedettek voltak a munka-magánélet egyensúlyukkal, azonban érdekes, hogy a férfiak közt mégis több volt a házas, szignifikánsan több gyermekük volt, a 40 évnél idősebb kutatónők körében pedig kiugróan magas volt a gyermektelenek aránya. Tehát ezen adatok szerint a nők számára objektíve nehezebbnek tűnik összeegyeztetni a magánéletet a tudományos munkával. Mindazonáltal a külföldön dolgozó, PhD-fokozattal rendelkező nők szubjektíve könnyebbnek érezték a munka-magánélet összehangolását külföldön, mint Magyarországon.

A PhD-fokozat tudományterületét tekintve a mintánkban is látható volt a horizontális szegregáció, összhangban a nemzetközi szakirodalommal (Xie - Shauman 2003): a természettudományok területén szignifikánsan több férfi, a társadalom- és bölcsésztudományoknál több nő vett részt a vizsgálatban. A vertikális szegregáció ugyanúgy megmutatkozott, mert a nők között kevesebben rendelkeztek DSc-fokozattal, munkáját tekintve több férfi töltött be vezető beosztást, ahol átlagosan több kutatási projektet is vezettek. Bár a férfiak és nők tudományos teljesítményében nem találtunk szignifikáns különbséget, a nők munkaerőpiaci pozíciója több tekintetben is bizonytalanabbnak bizonyult: többen éltek meg külföldi munkanélküliséget és a határozatlan idejű szerződés előtt jellemző volt a határozott idejű szerződéses foglalkoztatásuk. Ezen eredményekkel összhangban a férfiak elégedettebbek voltak jelenlegi munkaerőpiaci helyzetükkel és a PhD-fokozat munkaerőpiaci megtérülésével, mint a nők. Anyagi és egzisztenciális szempontból szintén több férfi volt elégedett a fokozat hasznosíthatóságával. Összességében a nőkre jellemzőbb volt a „mérsékelt” elégedettség, a férfiak pedig inkább „teljesen” elégedettek voltak a fokozat megtérülésével kapcsolatban.

Kutatásunk hipotézise szerint azt feltételeztük, hogy a nők objektíve és szubjektíve is hátrányosabb helyzetben vannak a külföldre menő magyar kutatók körében a férfiakhoz képest mind a családösszetétel, a munka-magánélet összehangolása, a tudományos és munkahelyi előmenetel és a PhD fokozatszerzés megtérülésének tekintetében. Kutatásunk eredményei alapján látni lehet, hogy a külföldön tartósan dolgozó magyar kutatók szakmai életútja során kombinálódhatnak az „otthonról hozott” hátrányok és a befogadó országra jellemző nemek közötti egyenlőség/egyenlőtlenség fejlettségének megfelelő hatások.

Fontos leszögezni, hogy a fent ismertetett egyenlőtlenségek ellenére, a kutatók döntő többsége alapvetően sikeresnek értékelte saját élet- és karrierútját. Szintén a nemzetközi mobilitással összefüggő előnyös kimenet, hogy a férfiak és nők tudo- 


\section{KÖZELKÉP}

mányos teljesítményében nem mutatkozott szignifikáns különbség. A férfiak ugyan gyakrabban voltak vezetői beosztásban, de pozitívum, hogy a különbség nem volt szignifikáns. Tehát a vertikális szegregáció bizonyos dimenzióiban azt mondhatjuk, hogy kisebb egyenlőtlenségek mutatkoztak, vagy nem jelentkeztek meghatározó mértékben. Szintén a külföldi munkavállalás előnyös kimenetére utal a szubjektív munka-magánélet egyensúlyának magasabb fokozata, illetve a férfiak és nők véleménye közötti nem szignifikáns különbségek.

A tradicionáis hátrányok közül megmaradt a „horizontális szegregáció” vagyis a PhD-fokozat tudományterület szerinti jelentős nemi különbségek. Szintén a hagyományos férfi és női szerepekre vezethető vissza, hogy a nemzetközileg mobil női kutatók nem elhanyagolható hányada a férfi partnerüket követte, mint hozzátartozó (tied movers) még akkor is, ha saját jogon is rendelkeztek PhD-val. Ez a kezdeti támogató döntés a kutatás adatai szerint a későbbiekre is kihatással van, a jövőben tartósan megmarad és nagyobb valószínúséggel vezet pályaelhagyáshoz - ahogyan arra más, kettős karriereket vizsgáló kutatás is rávilágított (Vohlídalová 2014). Ez a családi szerepekben megmutatkozó alárendeltség később a férfi partnernél materializálódhat munkaerőpiaci biztonságban, vezető beosztásban, több projekt vezetésében, magasabb tudományos fokozatban, mint amire jelen kutatás is rámutatott. Kutatásunkban a tartós nemzetközi mobilitás során tapasztalt egyik legfontosabb egyenlőtlenség a gyermekvállaláshoz kapcsolódik. A vizsgálat egyértelmúen eltérő mintázatokat mutatott a férfiak és nők gyermekvállalásával kapcsolatban a nők hátrányára. Míg a 40 év alatti férfiak és nők körében még nincsenek megfigyelhető különbségek a gyermekvállalásban, addig a gyermektelen és egygyermekes kutatónők magas aránya, különösen a 40 év feletti korosztályban, felhívja a figyelmet arra, hogy a külföldön dolgozó, magasan képzett nők ugyanúgy „nagyobb árat fizetnek” a családalapítás kapcsán, mint nemzetközi társaik (Mason et al 2013).

Kutatásunk azonban nem korlátok nélküli; a hólabdás módszer következtében nem tudtunk reprezentatív mintán dolgozni, és az eredmények szélesebb általánosíthatóságra nem alkalmasak. Viszont egy nagyon nehezen elérhető célcsoport esetében a módszer célravezetőnek mutatkozott, és lehetőséget engedett főbb mintázatok, a nemek közötti egyenlőtlenségek egyes fontos aspektusainak kimutatására. Jövőbeli kutatásoknak érdemes megvizsgálniuk, hogy a fiatal magyar kutatói generációban hogyan változnak a nemi szerepek, és ezek lehetővé teszik-e a gyermekvállalással kapcsolatos egyenlőtlenségek csökkentését - akár Magyarországon, akár külföldön dolgoznak - egy olyan időszakban, amikor a kutatókkal szemben egyre nagyobb teljesítményelvárás mutatkozik, beleértve a nemzetközi mobilitás és együttmúködés fokozódó tendenciáit is. 


\section{KÖZELKÉP}

\section{Irodalom}

Abramo, G. - D’Angelo, C. A. - Di Costa, F. (2009): Research collaboration and productivity: Is there correlation? Higher Education, 57(2): 155-171. https:// doi.org/10.1007/s10734-008-9139-z

Ackers, L. (2004): Managing relationships in peripatetic careers: Scientific mobility in the European Union. Women's Studies International Forum, 27(3): 189-201. https://doi.org/10.1016/j.wsif.2004.03.001

Berryman, S. E. (1983): Who will do science? Trends, and their causes in minority and female Representation among holders of advanced degrees in science and mathematics. A Special Report. Rockefeller Foundation, New York

Bilecen, B. - Van Mol, C. (2017): Introduction: International academic mobility and inequalities. Journal of Ethnic and Migration Studies, 43(8): 1241-1255. https:// doi.org/10.1080/1369183X.2017.1300225

Blaskó Z. - Ligeti S. A. - Sik E. (2014): Magyarok külföldön - Mennyien? Kik? Hol? In: Kolosi T. - Tóth Gy. I. - Török G. - Tóth Cs. - Fábián Z. - Kovács A. - Palócz É. (szerk.): Társadalmi Riport 2014. Tárki, Budapest, 351-372.

Cañibano, C. - Fox, M. F. - Otamendi, F. J. (2016): Gender and patterns of temporary mobility among researchers. Science and Public Policy, 43(3): 320-331. https:// doi.org/10.1093/scipol/scv042

Csanády M. - Személyi L. (2006): Brain drain. Közelkép a diplomás magyarokról. Századvég, 41: 3.

Davenport, C. (2004): The promise of democratic pacification: An empirical assessment. International Studies Quarterly, 48(3): 539-560. https://doi.org/ 10.1111/j.0020-8833.2004.00314.x

European Commission (2017): MORE3 study: Support data collection and analysis concerning mobility patterns and career paths of researchers. Publications Office. https://data.europa.eu/doi/10.2777/710643 (Utolsó letöltés ideje: 2020. 12. 05.)

Fábri G. (2018): A doktori fokozat értéke a munkaerőpiacon - a doktoráltak véleménye alapján. Kultúra és Közösség, 9(4): 49-58.

Fényes H. (2018): Mennyit ér egy tudományos fokozat - különös tekintettel a tudományos eredményesség és előmenetel nemi különbségeire. Szociológiai Szemle, 28(1): 60-82.

Fernandez-Zubieta, A. - Marinelli, E. - Pérez, S. E. (2013): What drives researchers' careers? The role of international mobility, gender and family. Sociology and Technoscience, 3(3): 8-30.

González Ramos, A. M. - Bosch, N. V. (2013): International mobility of women in science and technology careers: Shaping plans for personal and 


\section{KÖZELKÉP}

professional purposes. Gender, Place \& Culture, 20(5): 613-629. https://doi. org/10.1080/0966369X.2012.701198

Horváth Á. - Kmetty Z. (2008): Mást gondolnak a világról? A külföldön élő magyarországi diplomások értékrendje. Társadalmi Regiszter, 1: 153-171.

Jöns, H. (2011): Transnational academic mobility and gender. Globalisation, societies and education, 9(2): 183-209. https://doi.org/10.1080/14767724.2011.577199

Kim, T. (2009): Transnational academic mobility, internationalization and interculturality in higher education. Intercultural Education, 20(5): 395-405. https:// doi.org/10.1080/14675980903371241

Kim, T. (2017): Academic mobility, transnational identity capital, and stratification under conditions of academic capitalism. Higher Education, 73(6): 981-997. https://doi.org/10.1007/s10734-017-0118-0

Központi Statisztikai Hivatal (2011): A doktori fokozattal rendelkezők életpályája. Statisztikai Tükör, 3.

Központi Statisztikai Hivatal (2016): Mikrocenzus 2016. Központi Statisztikai Hivatal

Központi Statisztikai Hivatal (2019): Kutatás-fejlesztés 2018. Központi Statisztikai Hivatal

Loeb, J. W. (2006). The status of female faculty in the US: Thirty-five years with equal opportunity legislation. Management Revue, 157-180. https://doi.org/ 10.5771/0935-9915-2006-2-157

Mason, M. A. - Wolfinger, N. H. - Goulden, M. (2013): Do babies matter? Gender and family in the ivory tower. Rutgers University Press, New Jersey. https://doi. org/10.36019/9780813560823

OECD (2013): Key findings of the OECD-Knowinno project on the careers of doctorate holders. OECD. http://www.oecd.org/sti/inno/CDH\%20FINAL\%20REPORT-. pdf (Utolsó letöltés ideje: 2020. 12. 05.)

Paksi V. (2014): A magasan képzett nők gyermekvállalása és a tudományterület hatása. Kultúra és Közösség, 45(4): 143-151.

Schaer, M. - Dahinden, J. - Toader, A. (2017): Transnational mobility among early-career academics: Gendered aspects of negotiations and arrangements within heterosexual couples. Journal of Ethnic and Migration Studies, 43(8): 1292-1307. https://doi.org/10.1080/1369183X.2017.1300254

Stark, O. - Helmenstein, C. - Prskawetz, A. (1998): Human capital depletion, human capital formation, and migration: A blessing or a "curse"? Economics Letters, 60(3): 363-367. https://doi.org/10.1016/S0165-1765(98)00125-6 


\section{KÖZELKÉP}

Tardos K. - Paksi V. (2020): Tudományos karrierutak kutatói értékelése: Női és férfiperspektívák. In: A. Gergely A. - Kapitány Á. - Kapitány G. - Kovács É. - Paksi V. (szerk.): Kultúra, közösség és társadalom. Tanulmányok Tibori Timea tiszteletére. Centre for Social Sciences - Magyar Szociológiai Társaság, Budapest, 93-122.

Toader, A. - Dahinden, J. (2018): Family configurations and arrangements in the transnational mobility of early-career academics: Does gender make twice the difference? Migration Letters, 15(1): 67-84. https://doi.org/10.33182/ml. v15i1.339

Tzanakou, C. (2017): Dual career couples in academia, international mobility and dual career services in Europe. European Educational Research Journal, 16(2-3): 298-312. https://doi.org/10.1177/1474904116683185

Uhly, K. M. - Visser, L. M. - Zippel, K. S. (2015): Gendered patterns in international research collaborations in academia. Studies in Higher Education, 1-23. https:// doi.org/10.1080/03075079.2015.1072151

Vohlídalová, M. (2014): Academic mobility in the context of linked lives. Human Affairs, 24(1): 89-102. https://doi.org/10.2478/s13374-014-0208-y

Xie, Y. - Shauman, K. A. (2003): Women in science: Career processes and outcomes. Harvard University Press, Cambridge, MA

Zippel, K. (2011): How gender neutral are state policies on science and international mobility of academics? Sociologica, 1. https://doi.org/10.2383/34631 